nych koncepcji i innych. Autor z pewnością wiele czasu poświęcił na zebranie tak doskonałego materiału badawczego w języku polskim, niemieckim, angielskim, francuskim. Poświęcony czas owocuje, dobra publikacją, o logicznym i przejrzystym toku myślowym, która czyta się swobodnie. Przeszkodą w lekturze materii mogą być zbyt obszerne opisy historyczne, które sprawiają, że czasami odnosi się wrażenie, że czyta się o rzeczach oczywistych. Autor jak i wydawca zadbali, aby najważniejsze informacje dotarły do czytelnika, bowiem konkluzje, hipotezy i tezy są wydrukowane wythuszczonym drukiem.

MIKOEAJ J. TOMASZYK

Poznań

\title{
Tomasz Kubin, Polityczne implikacje wprowadzenia unii walutowej w Europie, Wydawnictwo Uniwersytetu Śląskiego, Katowice 2007, ss. 368.
}

Dnia 1 stycznia 1999 roku na obszarze jedenastu spośród piętnastu krajów członkowskich Unii Europejskiej zaczęła funkcjonować unia walutowa ${ }^{1}$. Stała się ona ostatnim etapem integracji gospodarczej w Europie, zapoczątkowanej już w 1950 roku przez francuskiego ministra spraw zagranicznych Roberta Schumana, który zaproponował koordynację wydobycia strategicznych dla historii Europy surowców i utworzenie Europejskiej Wspólnoty Węgla i Stali. Kolejne podwaliny pod europejski proces integracji położono w 1958 roku, kiedy na mocy Traktatu Rzymskiego powołano Europejską Wspólnotę Gospodarczą. Organizacja składała się początkowo z sześciu państw członkowskich, jednak w przeciagu następnych lat ich liczba poszerzyła się do piętnastu. Mocą Traktatu z Maastricht podpisanego 7 lutego 1992 roku Europejska Wspólnota Gospodarcza została przekształcona we Wspólnotę Europejską, sam traktat powołał zaś do życia nową Unię Europejską. Wspólna polityka gospodarcza prowadzona w ramach państw członkowskich EWG została w nim poszerzona i uzupełniona o nowe kompetencje i zadania, spośród których kluczowym okazała się być Unia Gospodarcza i Walutowa.

Stworzenie Unii Gospodarezej i Walutowej stało się jednym z najważniejszych wydarzeń w historii kontynentu europejskiego. Oto z początkiem 2002 roku dwanaście krajów członkowskich Unii Europejskiej zrezygnowało z własnej waluty, celem połączenia wspólnym pieniądzem swoich gospodarek. I choć historia samego euro jest krótka, proces który doprowadził do jego wprowadzenia rozpoczął się wiele lat wcześniej.

Zagadnienie wspólnej waluty stało się obszarem zainteresowania Tomasza Kubina, który postanowił opisać jej historię i teraźniejszość w pracy Polityczne implikacje wprowadzenia unii walutowej w Europie.

Omawiana książka została podzielona na sześć rozdziałów, wstęp i zakończenie, których treść uzupełniona została wykazem stosowanych w dziele skrótów, bibliografią oraz sporządzonym w języku angielskim i niemieckim podsumowaniem.

W pełniącym rolę wprowadzenia rozdziale I Autor przedstawia system powiązań, jaki charakteryzuje polityczną i ekonomiczną integrację Europy. Ta część pracy podkreśla, że UGiW nie jest jedynie kolejnym, gospodarezym etapem w drodze do pełnej integracji państw - przeciwnie, przedstawione w rozdziale opinie uznanych autorów wskazują jak silne jest połączenie ekonomii i polityki, zarówno w dziedzinie integracji walutowej, jak i integracji europejskiej w ogóle.

1 Dwunastym czlonkiem UGiW zostala Grecja 1 stycznia 2001 roku. 
Rozdział II koncentruje się na przedstawieniu znaczenia integracji. Pierwszy podrozdział definiuje pojęcie integracji, zarówno tej walutowej, jak i gospodarczej, zaś drugi prezentuje historyczne przykłady unii walutowych. Jak bowiem podkreśla Autor, Unia Gospodarcza i Walutowa stała się najważniejszym, jednak nie pierwszym przykładem wprowadzenia wspólnej waluty na świecie. Podrozdział wskazuje, iż porozumienia walutowe zawierano już w starożytności, a i w czasach obecnych wiele jest państw, które posiadają wspólną monetę. Faktem jest jednak, iż należą one do grupy krajów o niewielkim znaczeniu politycznym i gospodarczym, stąd wiedza o ich integracji, a także sam jej stopień, są niskie. Autor skupił swoją uwagę głównie na analizie czynników politycznych, które przyczyniły się do wprowadzenia i utrzymania integracji w tej sferze. Stąd też w rozdziale wprowadzono rozróżnienie na międzypaństwowe unie walutowe (jako przykład podano m.in. niemiecko-austriacką unię walutową ustanowioną w 1857 roku, czy unie walutowe utworzone przez byłe kolonie - Wschodniokaraibską Strefę Walutową z 1965 roku i unię walutową działającą w ramach Wspólnoty Wschodnioafrykańskiej w latach 1967-1977), oraz narodowe unie walutowe, czyli te, które zostały powołane celem wprowadzenia jedności politycznej na terenie danego kraju (przykładem stała się II Rzesza Niemiecka i unia walutowa powołana po zjednoczeniu Niemiec w 1990 roku). Całość rozdziału uzupełniona została dwoma tabelami, z których pierwsza wykazuje etapy procesu integracji i charakterystyczne dla nich cechy, zaś druga wymienia wszystkie międzypaństwowe unie walutowe krótko je charakteryzując.

Kolejny rozdział opisuje genezę procesów integracyjnych w Europie Zachodniej w drugiej połowie XX wieku. Ponadto przedstawia działania, które przyczyniły się do powstania UGiW - począwszy od pierwszych projektów unii walutowej, poprzez stworzenie zasad Europejskiego Systemu Walutowego, do podpisania Jednolitego Aktu Europejskiego i znaczenia, jakie miał on dla powołania UGiW. Zawarty w tej części pracy szczegółowy opis poszczególnych aktów prawnych tworzących Europejską Wspólnotę Gospodarczą pozwala na dokładną analizę procesu powstawania unii walutowej, zaś ostatnia cześś rozdziału, odnosząca się do utworzenia Unii Gospodarczej i Walutowej, umożliwia zapoznanie się z najważniejszymi dokumentami tworzącymi Unię Europejską, warunkami uczestnictwa w UGiW oraz kryteriami konwergencji. Rozdział uzupełniają tabele zawierające informacje na temat etapów tworzenia UGiW oraz realizacji warunków udziahu w trzeciej fazie unii walutowej.

Polityczne implikacje wprowadzenia wspólnej waluty w Europie stały się przedmiotem rozdziału IV. Autor próbuje w nim znaleźć odpowiedź na pytanie jak mocno europejski pieniądz wpłynął na suwerenność państw członkowskich, choć jak podkreśla, pojęcie suwerenności wywołuje często duże kontrowersje. Kontynuacją rozważań nad suwerennością państwową jest drugi podrozdział opisujący zależność między unią walutową a niezależnością gospodarczą państwa narodowego. Analiza wpływu, jaki wspólny pieniądz może mieć na funkcjonowanie i pozycję międzynarodową państwa narodowego stały się przedmiotem trzeciego podrozdziału (szczególną uwagę zwrócono na integrację europejską, nie zapominając jednak o innych aspektach mających wpływ na dzisiejszą politykę, jak chociażby globalizacja czy wzrost znaczenia aktorów pozapaństwowych na arenie międzynarodowej). Czwarty z podrozdziałów opisuje zaś znaczenie, jakie UGiW uzyskała w ramach rozwiązania tzw. kwestii niemieckiej. Autor skupił się w nim na przedstawieniu rangi, jaką dla stworzenia Unii Europejskiej i wprowadzenia unii walutowej miało zjednoczenie dwóch państw niemieckich.

Noszący tytuł „Polityczne implikacje unii walutowej dla Unii Europejskiej (państw członkowskich UGiW) jako całości" rozdział V wskazuje jak Unia Gospodarcza i Walutowa może w przyszłości doprowadzić do integracji politycznej swoich członków. Autor wskazuje w nim czynniki powodujące pogłębianie współpracy w tym wymiarze, mogące w przyszłości poskutkować powołaniem unii politycznej. Pierwszy podrozdział prezentuje cztery teorie integracji politycznej - federalizm, funkcjonalizm i neofunkcjonalizm, konfederalizm oraz, jak nazwał je Autor, podejście „transakcyjne”. Na podstawie wymienionych teorii T. Kubin w ciekawy sposób 
objaśnia koncepcję rozwoju współpracy europejskiej od samego jej początku, aż do ostatnich lat. Podrozdział drugi przedstawia najważniejsze organy i instytucje Unii Europejskiej, których obszar działania odnosi się do Unii Gospodarczej i Walutowej (Rada Europejska, Rada Unii Europejskiej, Europejski System Banków Centralnych oraz Europejski Bank Centralny, Komisja Europejska i Komitet Ekonomiczno-Finansowy). Szczególnie interesująco ukazane zostały zagadnienia legitymizacji Europejskiego Banku Centralnego i odpowiedzialności politycznej, którą on ponosi. Tę cześć pracy uzupełniają dwie tabele przedstawiające federalizm jako model dwóch przeciwstawnych tendencji polityeznych - integracji oraz decentralizacji; a także system instytucjonalny UGiW.

Rozdział VI, ostatni, zawiera opis związków łączących globalny układ sił z kształtem systemu walutowego, a także polityczne konsekwencje wprowadzenia unii walutowej w ramach państw członkowskich UE dla pozostałych aktorów międzynarodowej sceny politycznej. Jak bowiem podkreśla Autor ,wprowadzenie UGiW przez państwa UE, a więc kraje bardzo wysoko rozwinięte i o bardzo istotnym znaczeniu dla gospodarki światowej, wiąże się także z konsekwencjami o charakterze globalnym" (s. 310). Rozdział uzupełniają trzy tabele dotyczące finansów Stanów Zjednoczonych, które uznane zostały za najważniejsze państwo w powojennym systemie walutowym świata.

Zakończenie będące podsumowaniem zagadnień podejmowanych w ramach dzieła, bibliografia oraz streszczenia w języku angielskim i niemieckim zamykają pracę.

Podział tematyczny monografii na sześć rozdziałów pozwala czytelnikowi zaznajomić się z wieloma aspektami integracji walutowej, zarówno w jej politycznym, jak i ekonomicznym wymiarze. Zdaniem T. Kubina wprowadzenie wspólnego pieniądza miało tylko pozornie znaczenie wyłącznie gospodarcze - ekonomiczne motywy wprowadzenia euro miały bowiem przyczynić się do zwiększenia wzrostu gospodarczego, zmniejszenia bezrobocia, przyspieszenia wzrostu PKB, a w konsekwencji do podniesienia poziomu dobrobytu mieszkańców Europy Zachodniej. Celem na przyszłość jest zaś, przy pomocy integracji walutowej, zwiększenie współpracy, a może nawet powołanie unii politycznej.

Lektura jest bardzo ciekawie sporządzonym kompendium wiedzy na temat historii, zasad funkcjonowania i politycznych konsekwencji wprowadzenia euro zarówno dla państw członkowskich Unii Europejskiej, jak i całej społeczności międzynarodowej. Warto podkreślić, iż jest to jedyne takie dzieło na polskim rynku - większość autorów koncentruje się bowiem na gospodarczych aspektach wprowadzenia wspólnej waluty - T. Kubin zaś podkreśla znaczenie polityczne tego procesu.

W tym miejscu docenić należy wysiłek, jaki Autor włożył w przygotowanie tak obszernego opracowania. Benedyktyńska praca i czas spędzony w zagranicznych bibliotekach (szczególny nacisk położono na wydawnictwa angielskojęzyczne) z pewnością przyczyniły się do uzyskania wysokiej wartości merytorycznej monografii. Dla czytelnika nieco uciążliwe może być jedynie używanie dużej ilości cytatów z zagranicznych autorów (szczególnie w rozdziale I), jednak na pochwałę zasługuje fakt samodzielnego, dobrego tłumaczenia.

Dzieło jest dowodem bardzo uważnej analizy polityki europejskiej ostatnich kilkudziesięciu lat i umożliwia zapoznanie się z aspektami funkcjonowania UGiW. Z pewnością nie jest to książka mogąca stanowić podręcznik do nauki historii europejskiej waluty, i do takiego miana nie aspiruje. Jest natomiast wartościową i szczególowo sporządzoną monografią zagadnienia, które dotyczy wszystkich mieszkańców Europy, w przyszłości bezpośrednio także Polski.

JOANNA CIESIELSKA 